\title{
MAGYAR ÉS HATÁRON TÚLI BENTLAKÁSOS LABDARÚGÓ AKADÉMIA SAJÁTOSSÁGAI AZ EDZŐ SZEREPE ÉS JELLEMZÖI TEKINTETÉBEN
}

\section{Szerzők:}

Kiss Zoltán

Eszterházy Károly Egyetem (Magyarország)

Dr. Csáki István (PhD.)

Testnevelési Egyetem (Magyarország)

Dr. habil. Bognár József (PhD.)

Eszterházy Károly Egyetem (Magyarország)
Lektorok:

Prof. Dr. Géczi Gábor (PhD.)

Testnevelési Egyetem (Magyarország)

Dr. habil. Tóth László (PhD.)

Testnevelési Egyetem (Magyarország)

Első szerző:

kiss.zoltan@pfla.hu

Kiss Zoltán, Csáki István, Bognár József (2019). Magyar és határon túli bentlakásos labdarúgó akadémia sajátosságai az edző szerepe és jellemzői tekintetében. Különleges Bánásmód, 5. (2). 7-18. DOI 10.18458/KB.2019.2.7

\begin{abstract}
Absztrakt
A labdarúgás határainkon kívül és belül egyaránt népszerúségnek örvend, annak a ténynek ellenére, hogy a jelenlegi magyar labdarúgás csak néhány olyan játékossal büszkélkedhet, akik nemzetközileg is jegyzett csapatokban szerepelnek. A tehetséggondozási folyamatban komoly felelősség hárul az utánpótlásedzőkre, hiszen nemcsak sportszakmailag kell kiemelkedőnek lenniük, hanem a fiatal játékosok életmódjára, hozzáállására és sporton kívüli tevékenységformáira is pozitív hatással kell lenniük. Mindezek alapján vizsgálatunk célja az, hogy bemutassuk az edzői szerepek tekintetében fellelhető különbségeket és hasonlóságokat a magyar és határon túli akadémia labdarúgói között, valamint az akadémiai korosztályok között.

A vizsgálatot Magyarország nyolc kiemelt akadémiájának egyikében, valamint egy határon túli akadémián végeztük el. A kutatás folyamán utánpótláskorú labdarúgókat $(\mathrm{n}=146)$ szólítottunk meg, akik négy különböző korosztályt képviseltek. A vizsgálat során kérdőíves módszert alkalmaztunk. A kikérdezés arra irányult, hogy milyen véleményt és tapasztalatot fogalmaznak meg a játékosok az edzői szereppel kapcsolatban.

A vizsgálat eredményei alapján elmondható, hogy a hazai és a határon túli akadémián nevelkedő fiatal játékosok és korosztályok is eltérően itélik meg edzőjük tevékenységét és az életükben betöltött szerepét. Az akadémiákat és a korosztályokat összehasonlítva lényeges különbségek fedezhetőek fel. A határon túli labdarúgók rendre magasabban értékelték az edzői szerepeket és az edzők fő jellemzőit, emellett egységesebb képet mutattak a korosztályok között. A hazai labdarúgók korban minél közelebb kerülnek a játékosok a profi szerződésekhez, annál inkább a továbblépéshez kapcsolódó tényezőket, míg a fiatalabbak főleg a pedagógiai részt emelték ki. Fontos lenne ezeknek megfelelő edzői tevékenység annak érdekében, hogy a pedagógiai tevékenység lényeges befolyásoló tényezőként jelenjen meg az utánpótlásnevelés folyamatában.
\end{abstract}

Kulcsszavak: labdarúgás, pedagógiai tevékenység, edzői szerep, tehetséggondozás Diszciplina: pedagógia, sportpedagógia 


\section{Abstract}

Football is equally popular in and around Hungary, despite the fact that currently Hungarian football has very few footballers who are good enough to play in internationally recognized teams. Youth trainers bear a special responsibility in talent development, as they not only have to be excellent sports professionals, but also need to have a positive influence on the young players' lifestyle, attitude and activities beyond sports. Based on the above, the purpose of the study was to explore differences and similarities in trainers' roles among the footballers in Hungary and in the Hungarian speaking areas of neighbouring countries. It was also our goal to take age into consideration of the football academies.

The study was carried out in of one the eight major football academies of Hungary, and at a football academy located in a Hungarian speaking area of a neighbouring country. In the study we gathered data from young footballers $(n=146)$ belonging to four age groups. We used the questionnaire method. The questions were aimed at the young footballers' attitudes and experience about the role of their trainers.

The findings show that the young players and age groups in and outside of Hungary have a different view on the work of their trainers and their influence on their life. Comparing the academies and the age groups, marked differences were found. The footballers of the neighbouring country generally tended to have a higher appreciation towards their trainers' roles and the main characteristics of their trainers, and also there were smaller differences between the age groups in that country. In the case of footballers from Hungary, the more they approached the age of being contracted as a professional sportsperson, the more they valued the factors affecting this step; while younger footballers mostly mentioned pedagogical elements. It would be important for trainers to be familiar with these findings and tailor their work accordingly, so that pedagogical work can play a crucial role in talent development.

Keywords: football, pedagogical work, the role of the trainer, talent development

Discipline: pedagogy, sports pedagogy

A jelenlegi magyar labdarúgás színvonala messze került még az 1970-es és -80-as évek eredményeitől is, amikor labdarúgó világbajnokságot ritkán rendeztek a magyar válogatott nélkül. Akkoriban még a klubcsapataink is bejutottak olykor valamelyik nemzetközi kupasorozat döntőjébe vagy az elődöntőbe. A labdarúgás jelenlegi sikertelensége több okra vezethető vissza, de a tehetséggondozás és az utánpótlásnevelés helyzete mindenképp fejlesztendô területnek túnik (Vincze és tsai, 2008). Hazánkban a labdarúgó akadémiák rendszere vállal kiemelt szerepet a fiatal labdarúgók komplex tehetséggondozásában és karrierjük hatékony elindításában, megalapozásában. A bentlakásos akadémiai rendszer a különböző szakmai és személyi problémák ellenére az elmúlt években a magyar labdarúgás-utánpótlás képzésének sarokkövévé vált (Kiss és tsai, 2015).

Jelen kutatás aktualitása az, hogy jelenleg a hazai labdarúgó akadémiák hatékonysága alig értékelhető nemzetközi szinten. A sikeres nemzetközi szerepléshez nem elég egy-egy motoros adottság magas szintû megléte, egyéb személyi és tárgyi tényezők is jelentős befolyással bírnak a beválás folyamatára (Révész és tsai, 2005).

A labdarúgás színvonalának emeléséhez elsősorban a fiatal tehetségek tudatos fejlesztésére van szükség, mely folyamatban a többet vizsgált motoros, antropometriai, pszichés tényezók mellett a pedagógiai elvek is jelentős szerepet játszanak (Csáki és tsai, 2013). Elmondható, hogy kevés azon hazai kutatások száma, mely az edző pedagógiai szerepét és az edző-sportoló kapcsolatot vizsgálja (Révész és tsai, 2013), és ez különösen igaz a labdarúgás sportágra. A sikeresség tekintetében lényeges az probléma, hogy az edző a sportszakmai fejlesztés mellett milyen nevelési módszerekkel és kommunikációval segíti a játékosok sokoldalú fejlódését, és ez mennyire befolyásolja a magatartásukat és milyen hatással lehet a felnőttkori teljesítményükre. 
A kérdéskörben az IPOO tanulás modelljét (Mező és Mezô, 2007) alkalmazva úgy fogalmazhatunk, hogy a fiatal sportolók beválására személyiségük is befolyással bír, így a még nem kiforrott pozitív személyiségvonások megerősítése az edzők privilégiuma is, melyet az edző - sportoló interakció során a megfelelő nevelési módszerek és stílusok alkalmazása (input: a sportolót érő, többékevésbé az edző által kontrollált ingerek, illetve ezek feldolgozása a process-fázisban) révén valósulhat meg. Az így kiteljesedő személyiségjegyek a játékosok magatartás és tevékenységformájában mutatkoznak meg (output). Ez a tanulási folyamat nem csak a pályán vagy az öltözőben valósulhat meg, hanem egyéb, közvetlenül a sporthoz nem kapcsolódó közös szabadidős programokon is realizálódhat (ez az organizáció fázisához köthető edzői szervezői tevékenységet igényel).

Az edző-sportoló kapcsolat pedagógiai szempontú vizsgálata úszók körében bemutatásra került Révész és mtsai által (2013), Gombocz és Gombocz (2006) utánpótláskorú kosárlabdázók edzőjükről alkotott elvárásaikat és véleményeiket vizsgálva kimutatták, hogy az edző megitélésében a szakmai hozzáértés és a pedagógiai tudás nagy jelentőséggel bír. Varga (2017) labdarúgó edzők véleményét vizsgálta a mester és utánpótláskorú tanítványai kapcsolatáról és azt állapította meg, hogy az edzők inkább a sportteljesítmény fejlesztésére irányuló tulajdonságokra helyeznek nagy hangsúlyt, szemben az erkölcsi és nevelési normákkal. Csáki és munkatársai (2013) fiatal labdarúgók körében végzett edző-sportoló kapcsolatának vizsgálata a posztok és a korosztályok között fellelhető jelentős különbségeket mutatta be. Rossmann (1987) az ideálisnak tartott és a reális edző sajátosságaira vonatkozó fiatal labdarúgók véleményeit vizsgálva azt találta, hogy a fiatal labdarúgók igénylik, hogy az edzők nagy figyelmet fordítsanak az egyéni fejlődésükre és partnerként kezeljék óket.

\section{Elméleti háttér}

Jól ismert, hogy az edző-sportoló kapcsolat meghatározza a sportbeli eredményességet és tel- jesítményt (Myers és tsai., 2005), valamint a fiatalok szocializációs folyamataira is jelentős hatással van (Gombocz, 2004). Az edző-sportoló kapcsolat jól jellemzi azt a pedagógiai viszonyhelyzetet is, mely elsősorban a közös célokon és a kölcsönös függőségen alapszik (Gombocz, 2010).

A szakmai ismeretek birtoklása mellett pedagógiailag is felkészültnek kell lennie az edzőnek ahhoz, hogy sikereket érjen el (Biróné, 2004). Az edző felelős azért, hogy az utánpótláskorú játékosok életének minden tényezője összhangban legyen egymással, illetve hogy személyiségük konstruktív módon egyesítse őket (Baumann, 2002). Az edzők számára fontos korszerű pedagógiai és pszichológiai ismeretek minél alaposabb elsajátítása és gyakorlatban történő alkalmazásának képessége, hiszen így nagyobb annak az esélye, hogy a különböző hatékony eljárások beépülnek a korosztályos nevelési és képzési folyamatok mindennapjaiba (Géczi és tsai, 2005).

A legtöbb fiatal sportoló példaképet választ magának, akinek a bőrébe (mezébe) bújva, azonosulhat vele a játék idôtartamára és titkon remélve, hogy egyszer ô is olyan sikeres sportoló lesz. A labdarúgó tehetséggondozásban részt vevô gyerekek előtt is az eszményképek sokfélesége jelenik meg, Makszin (2012) állítása szerint ezek lehetnek értelmi (a szabályok ismerete), erkölcsi (mint egy olimpiai bajnok) vagy gazdasági jellegű (kiemelkedő fizetés). A fiatalok a magatartásmintákat a különböző életkori szakaszaikban más-más személyektől kapják. A korai szakaszban a szülő, majd a pedagógusok a jelentik a példaképet, később az önértékelés és önismeret fejlődésével látókörük tágul, így a pubertáskorban tûnnek fel a mozaikpéldaképek, melyek több individuum követendő tulajdonságából állnak össze (Szebenyiné és Nyirkos, 1986). A példakép szerepe oldaláról kiemelésre érdemes, hogy az életkor és a sportágban elért eredmény változásával jelentôsen változik (Révész, Bognár és Géczi, 2007)

A tehetséggondozásban részt vevő fiatal labdarúgók számára az edző tudása és hozzáállása mellett a magatartásmintája is alapvető jelentőséggel bír. A gyerekek mozaik-példaképeikben fellelhető olyan pozitív jellemvonások, melyek erkölcsi tartalmat is hordoznak magukban, nagy valószínűséggel az edzőtől is származtathatóak. 
Kiváltképpen annak tükrében fontos ez a megállapítás, hogy az erkölcsi magatartásforma a jellemtôl függ, mely a személyiség magatartást meg-határozó belső feltételrendszerének legmagasabb eleme (Bábosik, 1991).

Megfelelő magatartásminta és motiváció nélkül a kiemelkedó értelmi és mentális képességek megléte esetén sem szabad tehetségrôl beszélni, hiszen belső kitartás, szorgalom, akaraterô nélkül a tehetséggondozás folyamata nem lehet eredményes (Czeizel, 1997). A magatartás és szokásrendszer nevelés útján kialakítható és fejleszthető, amennyiben kisgyermekkorban elkezdődik a teljesítményszükséglet tudatos fejlesztése (Biróné, 2004). A teljesítménymotiváció és a szorongáskezelés kiemelt szerepe mellett a sportolók nehezen érhetnek el sikereket az olyan személyiségjegyek nélkül, mint az önbizalom és az önbecsülés (Szepes, 2002), így ezeknek a tényezőknek is jelentős szerepet kell kapni a fiatal tehetségek fejlesztésében (Orosz, 2010).

A sikeresség eléréséhez a felkészülésen kívül a versengés is hozzájárul. Az együttmúködés és a versengés a társas motívum összetevői, a meg felelő szociális és érzelmi képességgel bíró sportolók magas fokon építik be a személyiségükbe és rendszeresen alkalmazzák a sporttevékenységben (Koltai és Bognár, 2009). Az edző számára fontos feladatot jelent a csapategység és optimális együttmúködés kialakítása, a csapat összetartásának erősítése és megszilárdítása. Amennyiben egy csapatnak sikerül egyesíteni a feladatkohéziót és a szociális összetartást, akkor optimális közösségi teljesítmény jöhet létre (Baumann, 2002). A feladatkohézió szintjei azt jelzik, hogy a csapattagok milyen mértékben dolgoznak együtt, míg a társas kohézió a csapattagok között fellelhető szimpátia mértékéről tanúskodnak (Lénárt, 2002).

A mindennapos edzői munka során megfigyelhetjük, hogy az edzők létrehoznak egy személyes stílust, ami rájuk jellemző. Baumann (2002) a tekintélyelvű, az együttmúködő és a kapcsolatorientált vezetői stílust különböztet meg az edzők vonatkozásában. A szerző kiemeli, hogy a sikeres edzők saját magatartásukat és követelményeiket a játékosok fejlettségi szintjéhez igazítják.
Jelen vizsgálat központi témája az edző szerepe és tulajdonsága, valamint az edző - sportoló interakcióban fellelhető pedagógiai viszony egy hazai és egy határon túli labdarúgó akadémián nevelkedő utánpótláskorú labdarúgók mintájában. Célunk bemutatni a hazai és határon túli labdarúgó akadémia edzői szerepeit és az edzők jellemző jegyeit az utánpótláskorú labdarúgó véleményei alapján. Ezen tényezők feltárásával megismerhető és fejleszthető az edzők pedagógiai tevékenysége, amely jelentős befolyásoló tényezőt mutat a beválás folyamatára és az eredményességre.

\section{MÓDSZER}

\section{Minta}

A vizsgálatot Magyarország nyolc kiemelt akadémiájának egyikében, valamint egy határon túli akadémián végeztük el. A kutatás folyamán utánpótláskorú labdarúgókat szólítottunk meg, akik négy különböző korosztályt (U-16, U-17, U-18 és U-19) képviseltek és valamennyien a saját intézményeik kollégiumában bentlakó fiatal sportolók. Mindkét adatfelvételi helyszínen az akadémiákat irányító testületek jóváhagyták a kutatáshoz tartozó etikai és módszertani tényezóket. A 18 év alatti gyerekek szülei írásban járultak hozzá a vizsgálatban való részvételhez, míg a már nagykorú sportolók maguk írták alá a beleegyező nyilatkozatot.

A teszteket a labdarúgók 2017-ben, az ôszi versenyidőszakban, a tanítási órák után, a délutáni tanulószobán töltötték ki. Az adatfelvételt a szerzők közül egy fő, valamint egy ügyeletes kollégiumi nevelő felügyelte. Mindannyian segítettek abban, hogy a tesztek lényegét a fiúk megértsék, valamint válaszoltak a felmerülő kérdésekre.

Hiányzás miatt három, illetve négy személy nem szerepel a mintában, a többiek az intézményben tartózkodtak ebben az időszakban. Összesen 146 labdarúgó válaszát dolgoztuk fel, ebből a hazai akadémiát 71 fó, a határon túli akadémiát 75 fó képviselte (1. táblázat). 
1. táblázat: A vizsgálatban szerepló játékosok számának korosztályonkénti megoszlása (forrás: a Szurzőó)

\begin{tabular}{|c|c|c|}
\hline U-16 & Hazai akadémia & $\begin{array}{c}\text { Hatóron tóli } \\
\text { akadémia }\end{array}$ \\
\hline U-17 & 17 fő & 20 fő \\
\hline U-18 & 19 fő & 18 fő \\
\hline U-19 & 16 fő & 25 fő \\
\hline$\Sigma$ & 71 fő & 12 fő \\
\hline
\end{tabular}

\section{Eszközök}

A vizsgálathoz olyan kérdőíves módszert alkalmaztunk, mely egy korábban alkalmazott kérdőív (Révész, Géczi és Vincze, 2005) labdarúgás sportágra történő adaptálásával történt. A kérdések az edző szerepére és az edző-sportoló kapcsolatot meghatározó tényezőkre térnek ki, mely során azt tárjuk fel, hogy miként tekintenek a sportolók edzőikre, illetve véleményük szerint milyen jellemzőik vannak az edzőknek. Az edzői szerepeket tekintve, a futballszakmai (menedzser, szakmai munkáért felel) és a labdarúgáson kívüli területeket érintő szerepek (barát, családtag) kerültek a vizsgálat fókuszába. Az edzői jellemzők esetében a fiatal labdarúgók saját tapasztalataik alapján kialakult véleményeikre és tapasztalataikra voltunk kíváncsiak. A kérdőív zárt jellegú kérdéseket tartalmazott, melyeket 1-tôl 5-ig terjedő attitűdskálán kellett meghatározni a játékosoknak, hogy mennyire értenek egyet az adott állítással. Az 1-es érték jelentette a kérdéssel vagy meghatározással való teljes egyet nem értést, az 5-ös érték pedig az állítással való teljes egyetértést.

\section{Eljárás}

Az adatok elemzéséhez az SPSS 20.0 statisztikai programot alkalmaztuk. A minta jellemzéséhez leíró statisztikát, a korosztályok közötti különbségek bemutatására varianciaanalízist (Post Hoc), a két akadémia sportoló csoportjai közötti különbségek bemutatására kétmintás T-próbát alkalmaztunk. Szignifikancia szintnek az 5\%-os hibahatárt vettük alapul.

\section{Eredmények}

Mind a hazai(h) és határon túli(ht) játékosoknál magas értékeket mutat a motivál $\left(M_{b}=4.01\right.$; $S D=1.16), \quad\left(M_{\mathrm{ht}}=4.55 ; S D=.77\right)$, tanár $\left(M_{h}=3.41\right.$; $S D=1.22), \quad\left(M_{b t}=3.99 ; \quad S D=1.07\right) \quad$ és példakép $\left(M_{b}=3.56 ; \quad S D=1.3\right), \quad\left(M_{b t}=3.96 ; \quad S D=.95\right) \quad$ míg kifejezetten alacsony a családtag $\left(M_{b}=2.15\right.$; $S D=1.31)\left(M_{b t}=2.96 ; S D=1.29\right)$ és a segít a stresszt elviselni $\left(M_{b}=2.76 ; S D=1.27\right)\left(M_{b t}=3.07 ; S D=1.18\right)$ változók értékei (1. ábra).

A határon túli akadémia a vizsgálati eredmények alapján kilenc esetben mutat szignifikánsan magasabb értékeket a hazainál. A határon túli játékosok véleménye alapján elmondhatjuk, hogy az edzőik nagyobb hangsúlyt fektetnek a motiválásra ( $t=$ 3.29; $p=.001)$ és a menedzseri feladatok ellátására is $(t=-5.28 ; p=.000)$, mint a hazai edzók. A szakmai munkán kívüli területen a határon túli sportolók magasabb értékekkel jellemzik edzőiket a barát $(t=-$ $2.55 ; p=.01)$, tanár ( $t=-3.03 ; p=.003)$, családtag ( $t=-$ $3.71 ; p=.000)$ szerepekben, valamint példaképként $(t=-2.1 ; p=.03)$ is jobban tekintenek rájuk, mint a hazai játékosok. 
1. ábra: „Az edződ szerepe az életedben”- kérdőiv skáláinak átlagértékei és szórásai a hazai és a határon túli labdarúgók mintájában (forrás: a Szerzó)

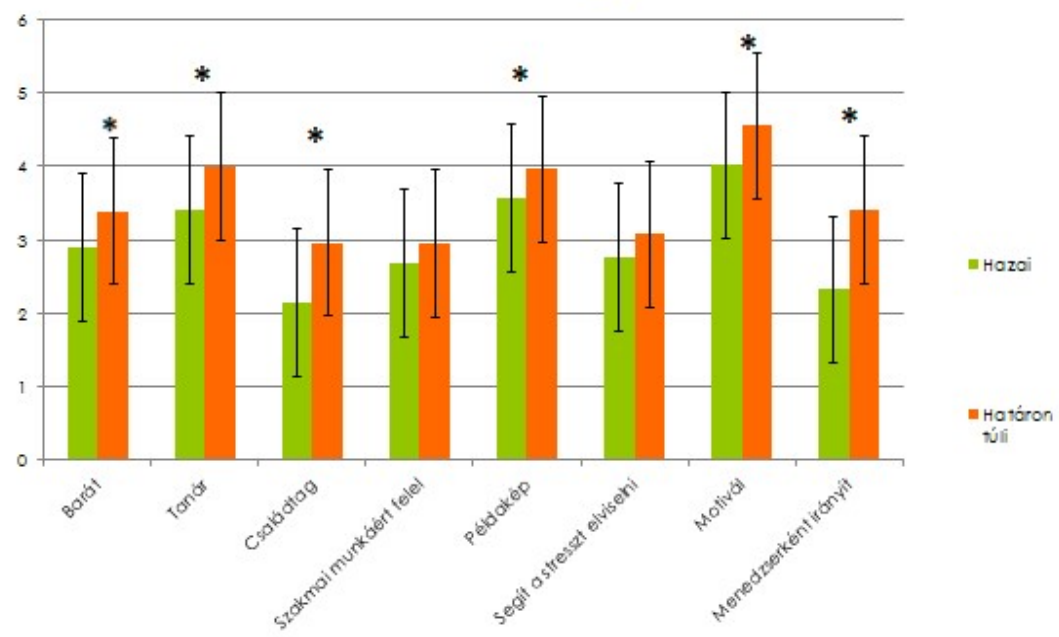

*Szignifikáns különbség a hazai és a határon túli labdarúgók között $(p<.05)$

Az edzői tulajdonságoknál kifejezetten alacsony értékeket mutat a teljesítményorientáltság $\left(\mathrm{M}_{\mathrm{h}}=2.48 ; \mathrm{SD}=1.22\right),\left(\mathrm{M}_{\mathrm{ht}}=2.65 ; \mathrm{SD}=1.09\right)$, a nem fontos az eredmény $\left(\mathrm{M}_{\mathrm{h}}=2.76 ; \quad \mathrm{SD}=1.19\right)$, $\left(\mathrm{M}_{\mathrm{ht}}=2.72 ; \mathrm{SD}=1.18\right)$ míg magas az előrelátó értéke $\left(\mathrm{M}_{\mathrm{h}}=4.17 ; \mathrm{SD}=1.2\right),\left(\mathrm{M}_{\mathrm{ht}}=4.47 ; \mathrm{SD}=.93\right)$.
Megállapítható, hogy a határon túli labdarúgók a civil életben is jobban támaszkodhatnak az edzőikre ( $t=-4.54 ; p=.000)$, akiket a vezető, irányító tulajdonság is jellemez ( $t=2.96 ; p=.004)$, valamint a csapategység kialakítása is fontos számukra ( $t=-$ 2.72; $p=.007)$, mint a hazai labdarúgók számára. (2. ábra)

2. ábra: „Az edződ jellemzői” — kérdöiv skáláinak átlagértékei és szórásai a hazai és a batáron túli labdarúgók mintájában (forrás: a Szeręó)

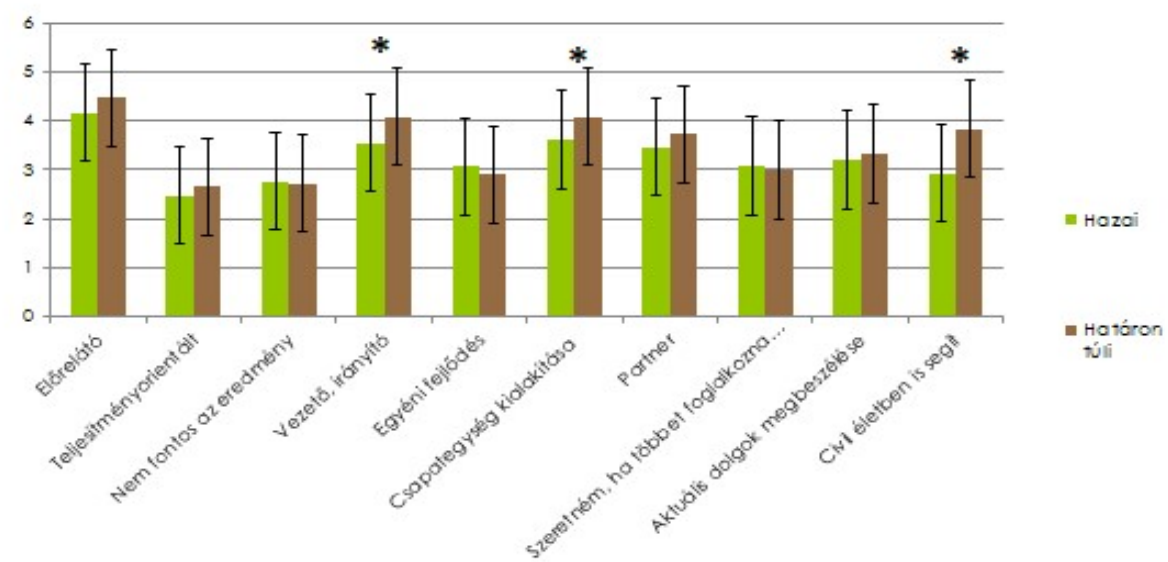

*Szignifikáns különbség a hazai és a határon túli labdarúgók között $(p<.05)$ 
Az edzői szerepeket tovább elemezve megállapíthatjuk, hogy a korosztályok között több kérdésben is különbség található. A példakép és a motiváló edzői szerepeket a korcsoportok a két intézményben eltérően ítélik meg. A hazai játékosok közül az U-18-as korúak a leginkább ( $F=2.86 ; p=.04)$, a határon túli U-18-as csapat tagjai a legkevésbé $(F=3.12 ; p=.03)$ tekintik edzőjüket példaképüknek. A hazai legidősebb korosztály érzi úgy, hogy edzôjük motiváló képessége a legala- csonyabb $(F=3.4 ; p=.02)$, ezzel szemben a határon túli U-19-es játékosok maximálisan elégedettek edzőjük teljesítményre való ösztönzésével ( $F=5.2$; $p=.003)$. A hazai U-18-asok gondolják úgy, hogy edzőjük nemcsak kizárólag a szakmai munkáért felelós személy ( $F=3.96 ; p=.01)$, valamint ó segít a legtöbbet abban, hogy a mindennapos stresszt elviseljék ( $F=3.04 ; p=.03)$. Az U-17-es korosztály játékosai edzőjük menedzseri tevékenységét emelik ki $(F=4.06 ; p=.01)$ (3. és 4. ábra).

3. ábra: „Az edzód szerepe az életedben”-kérdöiv skáláinak átlagai és szórásai a bazai labdarúgók korosztályonkénti megoszlásában (forrás: a Szerző)

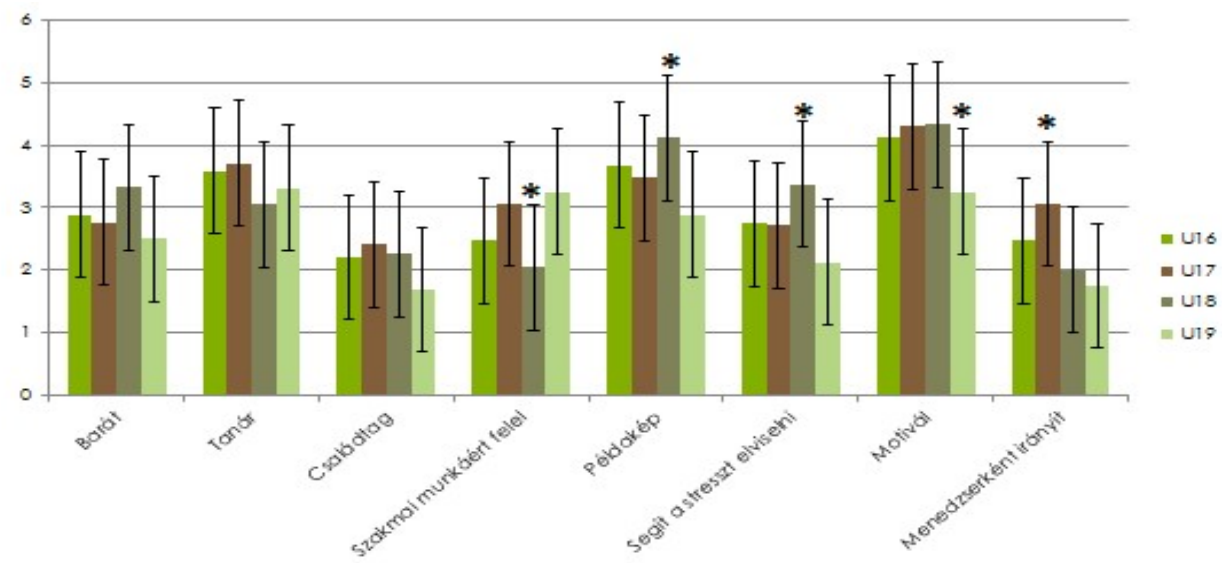

*Szignifikáns különbség a hazai labdarúgók korosztályai között $(p<.05)$

4. ábra: „Az edzốd szerepe az életedben” - kérdö́iv skáláinak átlagai és szórásai a határon túli labdarigók korosztályonkénti megoszlásában (forrás: a Szerzö)

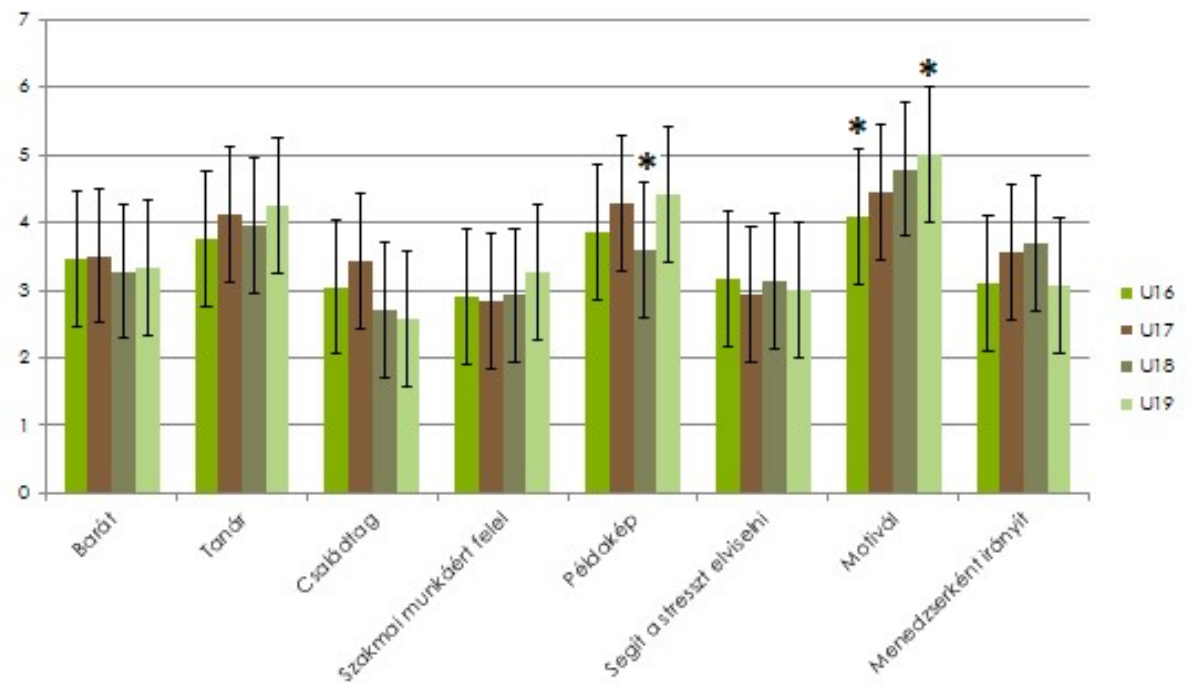

*Szignifikáns különbség a határon túli labdarúgók korosztályai között $(p<.05)$ 
Az edzői tulajdonságokat vizsgálva elmondhatjuk, hogy a korcsoportok között statisztikailag kimutatható különbséget csak a hazai akadémiánál találtunk. A legidősebb korosztály gondolja úgy, hogy az edzőjüknek leginkább az eredmény a fontos $(F=7.76 ; p=.000)$, szemben az U-17-esekkel, akiknek az edzőjük a mérkőzésre való felkészítésre helyezi a legnagyobb hangsúlyt $(F=3.89 ; p=.01)$. A 18 évesek az edzőjüket az előrelátással jellemzik $(F=6.31 ; p=.001)$, aki megtervezi a feladatokat és célokat tűz ki (5. és 6. ábra).

5. ábra: „Az edzód jellem zôio" - kérdöiv skáláinak átlagai és szórásai a hazai labdarúgók korosztályonkénti megoszlásában (forrás: a S žržö)

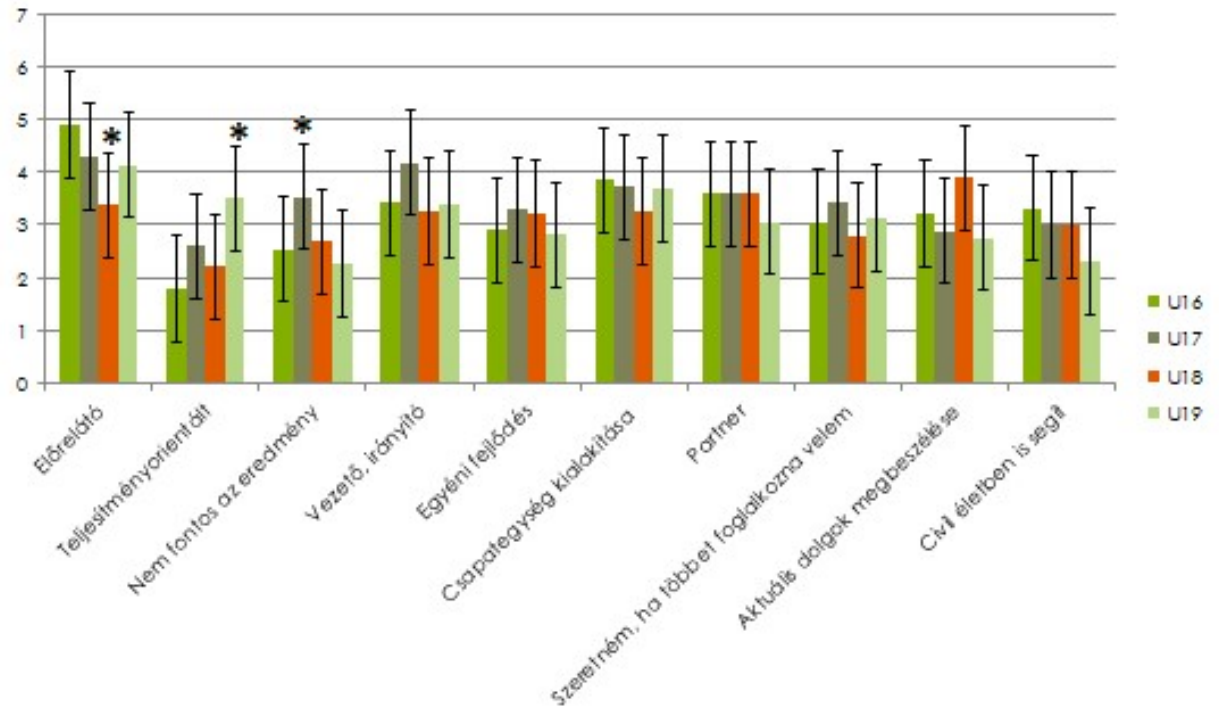

*Szignifikáns különbség a hazai labdarúgók korosztályai között $(p<.05)$

6. ábra: „Az edzớd jellemzói” - kérdöív skáláinak átlagai és szórásai a határon túli labdarígók korosztályonkénti megoszlásában (forrás: a Sžerzó)

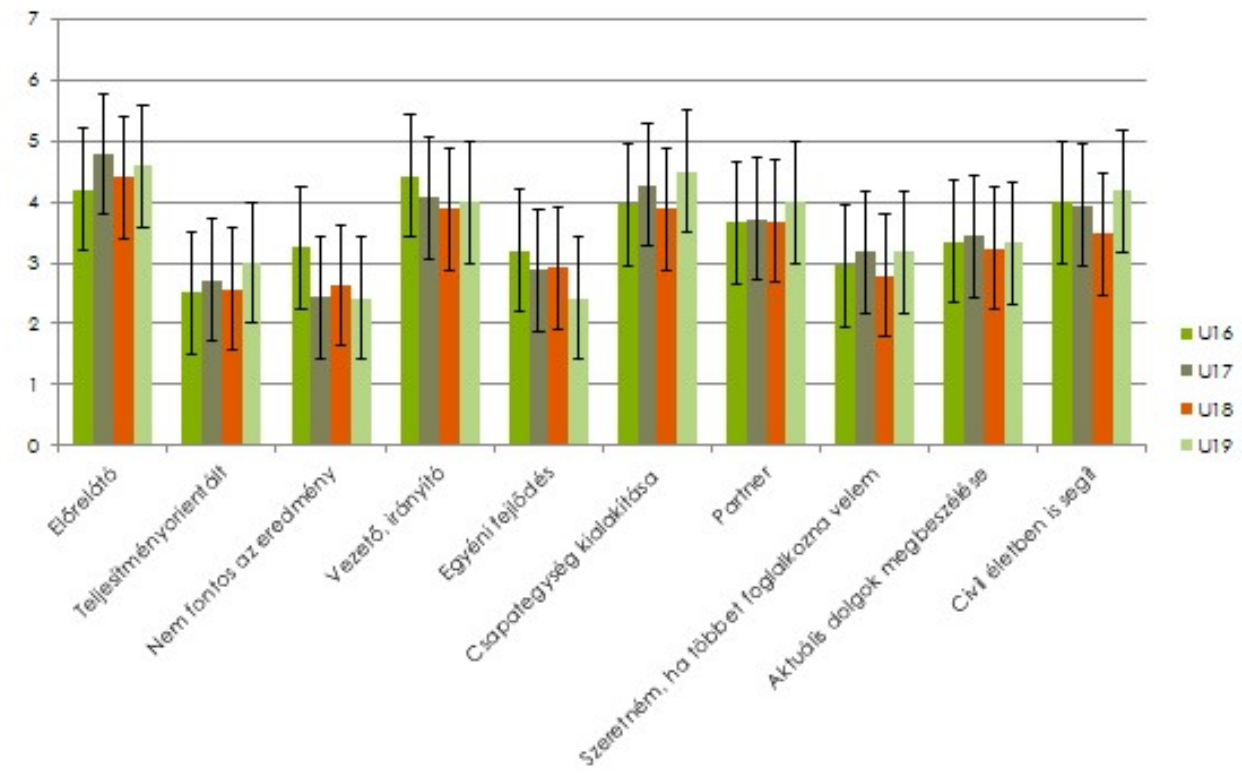

*Szignifikáns különbség a határon túli labdarúgók korosztályai között $(p<.05)$ 
Az edzői szerepeket összehasonlítva korosztályonként a hazai és a határon túli mintában 12 esetben találtunk szignifikáns különbséget. A két legfiatalabb korcsoportban a határon túli fiúk tekintenek inkább családtagként $(t=2.15 ; p=.03)$ és $(t=$ 2.3; $p=.02)$ az edzőjükre. A 18 éveseknél találjuk az egyetlen faktort, amelyben a hazai játékosok maga- sabb értékkel illetik edzőjüket, inkább ők tekintenek példaképként rá $(t=-2,47 ; p=.01)$. A legidősebb korosztályban található a legtöbb különbség, ahol külön kiemelhető a határon túli edző motivációs tevékenysége $(t=4.87$; $p=.000)$.(2.táblázat)

2. táblázat: „Az edzọ́d szerepe az életedben” - kérdöív skáláinak átlagai és szórásai a hazai (H) és a határon túli (HT) labdarúgók azonos korosztályok közötti megoszlásában (forrás: a Szerzô)

\begin{tabular}{|c|c|c|c|c|c|c|c|c|}
\hline \multirow[t]{3}{*}{ Változó } & \multicolumn{2}{|c|}{ U16 } & \multicolumn{2}{|c|}{ U17 } & \multicolumn{2}{|c|}{ U18 } & \multicolumn{2}{|c|}{ U19 } \\
\hline & $\mathrm{M} \pm \mathrm{SD}$ & $\mathrm{M} \pm \mathrm{SD}$ & $\mathrm{M} \pm \mathrm{SD}$ & $\mathrm{M} \pm \mathrm{SD}$ & $\mathrm{M} \pm \mathrm{SD}$ & $\mathrm{M} \pm \mathrm{SD}$ & $\mathrm{M} \pm \mathrm{SD}$ & $\mathrm{M} \pm \mathrm{SD}$ \\
\hline & $\mathrm{H}$ & HT & $\mathrm{H}$ & $\mathrm{HT}$ & $\overline{\mathrm{H}}$ & HT & $\mathrm{H}$ & HT \\
\hline Barát & $\begin{array}{c}2,89 \pm 1,2 \\
8\end{array}$ & $\begin{array}{c}3,42 \pm 1,3 \\
4\end{array}$ & $\begin{array}{c}2,76 \pm 1,4 \\
7\end{array}$ & $3,50 \pm 1,0^{*}$ & $3,5 \pm 1,29$ & $\begin{array}{c}3,29 \pm 0,9 \\
5\end{array}$ & $2,5 \pm 1,21$ & $\begin{array}{c}3,23 \pm 0,9 \\
2\end{array}$ \\
\hline Tanár & $\begin{array}{c}3,58 \pm 1,1 \\
7\end{array}$ & $\begin{array}{c}3,79 \pm 1,4 \\
3\end{array}$ & $\begin{array}{c}3,71 \pm 1,0 \\
4\end{array}$ & $4,1 \pm 0,96$ & $\begin{array}{c}3,22 \pm 1,1 \\
1\end{array}$ & $\begin{array}{c}3,92 \pm 0,8 \\
8^{*}\end{array}$ & $\begin{array}{c}3,31 \pm 1,3 \\
5\end{array}$ & $\begin{array}{c}4,31 \pm 0,9 \\
4^{*}\end{array}$ \\
\hline Családtag & $\begin{array}{c}2,21 \pm 1,1 \\
8\end{array}$ & $\begin{array}{c}3,05 \pm 1,2 \\
2 *\end{array}$ & $\begin{array}{c}2,41 \pm 1,2 \\
7\end{array}$ & $\begin{array}{c}3,45 \pm 1,4 \\
3 *\end{array}$ & $\begin{array}{c}2,39 \pm 1,4 \\
6\end{array}$ & $\begin{array}{c}2,67 \pm 1,1 \\
6\end{array}$ & $\begin{array}{c}1,69 \pm 1,2 \\
5\end{array}$ & $\begin{array}{c}2,46 \pm 1,3 \\
3\end{array}$ \\
\hline $\begin{array}{l}\text { Szakmai } \\
\text { munkaért } \\
\text { felel }\end{array}$ & $2,47 \pm 1,3$ & $\begin{array}{c}2,95 \pm 1,0 \\
2\end{array}$ & $\begin{array}{c}3,06 \pm 1,0 \\
2\end{array}$ & $2,8 \pm 0,89$ & $\begin{array}{c}2,17 \pm 1,1 \\
5\end{array}$ & $\begin{array}{c}2,92 \pm 1,2 \\
4\end{array}$ & $3,25 \pm 1,0$ & $\begin{array}{c}3,23 \pm 1,2 \\
3\end{array}$ \\
\hline Példakép & $\begin{array}{c}3,68 \pm 1,0 \\
0\end{array}$ & $\begin{array}{c}3,89 \pm 1,0 \\
4\end{array}$ & $\begin{array}{c}3,47 \pm 1,3 \\
7\end{array}$ & $4,2 \pm 0,69 *$ & $\begin{array}{c}4,33 \pm 0,8 \\
4 *\end{array}$ & $\begin{array}{c}3,58 \pm 1,0 \\
6\end{array}$ & $\begin{array}{c}2,88 \pm 1,3 \\
6\end{array}$ & $\begin{array}{c}4,46 \pm 0,6 \\
6 *\end{array}$ \\
\hline $\begin{array}{l}\text { Segít a } \\
\text { stresszt elv- } \\
\text { iselni }\end{array}$ & $\begin{array}{c}2,74 \pm 1,0 \\
4\end{array}$ & $\begin{array}{c}3,28 \pm 1,1 \\
2\end{array}$ & $\begin{array}{c}2,71 \pm 1,2 \\
6\end{array}$ & $\begin{array}{c}2,85 \pm 1,2 \\
2\end{array}$ & $\begin{array}{c}3,56 \pm 1,3 \\
8\end{array}$ & $\begin{array}{c}3,13 \pm 1,2 \\
9\end{array}$ & $2,13 \pm 0,8$ & $\begin{array}{c}3,15 \pm 1,1 \\
4^{*}\end{array}$ \\
\hline Motivál & $\begin{array}{c}4,11 \pm 0,9 \\
9\end{array}$ & $\begin{array}{c}4,05 \pm 1,1 \\
2\end{array}$ & $\begin{array}{c}4,29 \pm 0,8 \\
4\end{array}$ & $4,5 \pm 0,68$ & $4,56 \pm 0,7$ & $\begin{array}{c}4,78 \pm 0,4 \\
2\end{array}$ & $\begin{array}{c}3,25 \pm 1,2 \\
9\end{array}$ & $\begin{array}{c}5,00 \pm 0,0 \\
0^{*}\end{array}$ \\
\hline $\begin{array}{l}\text { Menedzserké } \\
\text { nt írányít }\end{array}$ & $\begin{array}{c}2,47 \pm 1,1 \\
7\end{array}$ & $\begin{array}{c}3,16 \pm 1,2 \\
5\end{array}$ & $\begin{array}{c}3,06 \pm 1,4 \\
3\end{array}$ & $3,5 \pm 1,35$ & $\begin{array}{c}2,11 \pm 1,0 \\
7\end{array}$ & $\begin{array}{c}3,67 \pm 0,9 \\
1 *\end{array}$ & $\begin{array}{c}1,75 \pm 0,8 \\
5\end{array}$ & $\begin{array}{c}3,23 \pm 1,4 \\
3^{*}\end{array}$ \\
\hline
\end{tabular}

*Szignifikáns különbség a hazai (H) és a határon túli (HT) labdarúgók azonos korosztályai között $(p<.05)$

Az edzői tulajdonságok tekintetében szintén 12 esetben találtunk szignifikáns különbséget a hazai és a határon túli korosztályokat tekintve. A hazai 16 éves fiúk tapasztalták azt, hogy leginkább az ő edzőjük tervezi meg a feladatokat és tűz ki célokat $(t=-2.43 ; p=.02)$, míg a határon túliak a vezető, irányító tulajdonságot emelik ki $(t=2.86 ; p=.007)$. A határon túli 17 és 19 éves játékosok érzik úgy leginkább, hogy edzőikre a sporton kívüli területeken is számíthatnak ( $t=2.39 ; p=.02)$ és ( $t=4.89 ; p=.000)$, míg a 18 éves hazai labdarúgók beszélik meg a leggyakrabban edzójükkel az aktuális dolgokat $(t=-2.9 ; p=.006,3$. táblázat). 
KÜLÖNLEGES BÁNÁSMÓD, V.ÉVF. 2019/2.

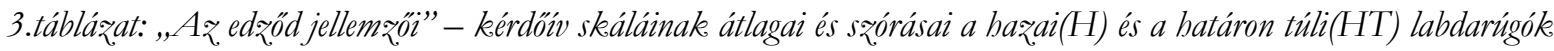
azonos korosztályok közötti megoszlásában (forrás: a Szerzö)

\begin{tabular}{|c|c|c|c|c|c|c|c|c|}
\hline \multirow[t]{3}{*}{ Változó } & \multicolumn{2}{|c|}{ U16 } & \multicolumn{2}{|c|}{ U17 } & \multicolumn{2}{|c|}{ U18 } & \multicolumn{2}{|c|}{ U19 } \\
\hline & $\mathrm{M} \pm \mathrm{SD}$ & $\mathrm{M} \pm \mathrm{SD}$ & $\mathrm{M} \pm \mathrm{SD}$ & $\mathrm{M} \pm \mathrm{SD}$ & $\mathrm{M} \pm \mathrm{SD}$ & $\mathrm{M} \pm \mathrm{SD}$ & $\mathrm{M} \pm \mathrm{SD}$ & $\mathrm{M} \pm \mathrm{SD}$ \\
\hline & $\mathrm{H}$ & $\mathrm{HT}$ & $\mathrm{H}$ & HT & $\mathrm{H}$ & HT & $\mathrm{H}$ & $\mathrm{HT}$ \\
\hline Előrelátó & $\begin{array}{c}4,89 \pm 0,3 \\
1 *\end{array}$ & $\begin{array}{c}4,21 \pm 1,1 \\
8\end{array}$ & $\begin{array}{c}4,29 \pm 1,2 \\
6\end{array}$ & $\begin{array}{c}4,75 \pm 0,9 \\
1\end{array}$ & $\begin{array}{c}3,56 \pm 1,2 \\
9\end{array}$ & $\begin{array}{c}4,38 \pm 0,8 \\
2^{*}\end{array}$ & $\begin{array}{c}4,13 \pm 0 \\
88\end{array}$ & $\begin{array}{c}4,62 \pm 0,6 \\
5\end{array}$ \\
\hline $\begin{array}{l}\text { Tejesítményori- } \\
\text { entált }\end{array}$ & $\begin{array}{c}1,79 \pm 0,8 \\
5\end{array}$ & $\begin{array}{c}2,53 \pm 1,0 \\
2 *\end{array}$ & $2,59 \pm 1,0$ & $\begin{array}{c}2,60 \pm 1,1 \\
4\end{array}$ & $\begin{array}{c}2,33 \pm 1,1 \\
8\end{array}$ & $\begin{array}{c}2,63 \pm 0,9 \\
7\end{array}$ & $\begin{array}{c}3,5 \pm 1,1 \\
5\end{array}$ & $\begin{array}{c}3,15 \pm 1,4 \\
3\end{array}$ \\
\hline $\begin{array}{l}\text { Nem fontos az } \\
\text { eredmény }\end{array}$ & $\begin{array}{c}2,53 \pm 1,1 \\
2 \\
\end{array}$ & $\begin{array}{c}3,26 \pm 1,0 \\
4^{*}\end{array}$ & $\begin{array}{c}3,53 \pm 1,2 \\
8^{*}\end{array}$ & $\begin{array}{c}2,50 \pm 1,1 \\
9\end{array}$ & $\begin{array}{c}2,83 \pm 0,9 \\
8\end{array}$ & $\begin{array}{c}2,61 \pm 1,1 \\
5\end{array}$ & $\begin{array}{c}2,27 \pm 0 \\
88\end{array}$ & $\begin{array}{c}2,31 \pm 1,3 \\
1\end{array}$ \\
\hline Vezetô, irányító & $\begin{array}{c}3,42 \pm 1,2 \\
1\end{array}$ & $\begin{array}{c}4,39 \pm 0,7 \\
7 *\end{array}$ & $\begin{array}{c}4,18 \pm 1,4 \\
2\end{array}$ & $\begin{array}{c}4,05 \pm 0,8 \\
8\end{array}$ & $\begin{array}{c}3,44 \pm 1,1 \\
9\end{array}$ & $\begin{array}{c}3,92 \pm 0,9 \\
2\end{array}$ & $\begin{array}{c}3,38 \pm 0, \\
71\end{array}$ & $\begin{array}{c}4,08 \pm 0,8 \\
6^{*}\end{array}$ \\
\hline Egyéni fejlődés & $\begin{array}{c}2,89 \pm 0,8 \\
7\end{array}$ & $3,32 \pm 1,1$ & $\begin{array}{c}3,29 \pm 1,2 \\
6\end{array}$ & $\begin{array}{c}2,74 \pm 1,0 \\
4\end{array}$ & $\begin{array}{c}3,39 \pm 1,0 \\
9\end{array}$ & $2,96 \pm 1,1$ & $\begin{array}{c}2,81 \pm 0 \\
98\end{array}$ & $2,31 \pm 1,1$ \\
\hline $\begin{array}{l}\text { Csapategység } \\
\text { kialakítása }\end{array}$ & $\begin{array}{c}3,84 \pm 0,8 \\
3\end{array}$ & $\begin{array}{c}3,95 \pm 1,1 \\
2\end{array}$ & $\begin{array}{c}3,71 \pm 1,2 \\
6\end{array}$ & $\begin{array}{c}4,30 \pm 0,7 \\
3\end{array}$ & $\begin{array}{c}3,44 \pm 1,1 \\
9\end{array}$ & $\begin{array}{c}3,83 \pm 0,9 \\
8\end{array}$ & $\begin{array}{c}3,69 \pm 0 \\
94\end{array}$ & $\begin{array}{c}4,54 \pm 0,7 \\
7 *\end{array}$ \\
\hline Partner & $\begin{array}{c}3,58 \pm 0,9 \\
6\end{array}$ & $3,68 \pm 1,2$ & $\begin{array}{c}3,59 \pm 1,4 \\
1\end{array}$ & $\begin{array}{c}3,70 \pm 0,9 \\
7\end{array}$ & $\begin{array}{c}3,78 \pm 1,3 \\
9\end{array}$ & $3,67 \pm 1,0$ & $\begin{array}{c}3,06 \pm 1 \\
12\end{array}$ & $\begin{array}{c}4,0 \pm 1,15 \\
*\end{array}$ \\
\hline $\begin{array}{l}\text { Szeretném, ha } \\
\text { többet foglal- } \\
\text { kozna velem }\end{array}$ & $\begin{array}{c}3,05 \pm 1,4 \\
3\end{array}$ & $\begin{array}{c}3,05 \pm 1,0 \\
7\end{array}$ & $\begin{array}{c}3,41 \pm 1,1 \\
7\end{array}$ & $\begin{array}{c}3,05 \pm 1,5 \\
3\end{array}$ & $\begin{array}{c}2,94 \pm 1,5 \\
5\end{array}$ & $\begin{array}{c}2,78 \pm 1,2 \\
4\end{array}$ & $\begin{array}{c}3,13 \pm 1 \\
36\end{array}$ & $\begin{array}{c}3,08 \pm 1,1 \\
8\end{array}$ \\
\hline $\begin{array}{l}\text { Aktuális dolgok } \\
\text { megbeszélése }\end{array}$ & $\begin{array}{c}3,21 \pm 1,0 \\
3\end{array}$ & $\begin{array}{c}3,37 \pm 1,1 \\
6\end{array}$ & $\begin{array}{c}2,88 \pm 1,3 \\
1\end{array}$ & $3,4 \pm 1,18$ & $\begin{array}{c}4,11 \pm 0,9 \\
6^{*}\end{array}$ & $\begin{array}{c}3,25 \pm 0,9 \\
4\end{array}$ & $\begin{array}{c}2,75 \pm 1 \\
06\end{array}$ & $\begin{array}{c}3,31 \pm 1,0 \\
3\end{array}$ \\
\hline $\begin{array}{l}\text { Civil életben is } \\
\text { segít }\end{array}$ & $\begin{array}{c}3,32 \pm 1,1 \\
5\end{array}$ & $\begin{array}{c}3,95 \pm 1,0 \\
2\end{array}$ & $\begin{array}{c}3,00 \pm 1,4 \\
5\end{array}$ & $\begin{array}{c}4,00 \pm 1,0 \\
7 *\end{array}$ & $\begin{array}{c}3,17 \pm 1,3 \\
3\end{array}$ & $3,46 \pm 1,1$ & $\begin{array}{c}2,31 \pm 1 \\
13\end{array}$ & $\begin{array}{c}4,23 \pm 09 \\
2 *\end{array}$ \\
\hline
\end{tabular}

*Szignifikáns különbség a hazai és a határon túli labdarúgók azonos korosztályai között $(p<.05)$

\section{Megvitatás}

Az edző-sportoló kapcsolat bizonyítottan jelentős szerepet játszik a fiatal sportolók mindennapjaiban, sportos és sporton kívüli jelenében és jövőjében is (Trzaskoma-Bicsérdy és tsai, 2007). Jelen vizsgálat eredményei alapján elmondható, hogy a hazai és a határon túli akadémián nevelkedő fiatal játékosok és korosztályok is eltérően itélik meg edzőjük tevékenységét és az életükben betöltött szerepét.

Elmondható, hogy statisztikailag kimutatható különbség kilenc esetben mutatkozott meg a két intézmény összehasonlítása során és valamennyi faktor estében a határon túli fiatalok jellemezték edzőiket a magasabb értékekkel.

Az edzői szerepeknél mindkét intézmény labdarúgói a tanár, a motivál és a példakép tényezőket magas pontszámmal értékelték. Egy korábbi vizsgálat eredményei alapján Csáki és munkatársai (2013) is azt találták, hogy a fiatal labdarúgók magas értékkel jellemezték az edzők tanár és példakép szerepét.

Az edzők tanári tevékenységformái nagy jelentőséggel bírnak az utánpótláskorú játékosoknál, hiszen egy-egy technikai elem elsajátítása vagy taktikai feladat megértése oktatási folyamat során valósulhat meg. Úszók körében végzett kutatás alkalmával kiemelésre került, hogy a sportolók fontosnak tartják az edzők motiváló szerepét (Révész és tsai., 2013).

Az edző - sportoló kapcsolat összefüggésében érdemes kiemelni, hogy inkább a határon túli labdarúgók tekintenek barátként, családtagként és menedzserként edzóikre, mint a hazaiak, annak ellenére, hogy jellemzően alacsony értékeket mutatnak ezek a tényezők. Valószínúsíthető, hogy a hazai játékosok kevésbé kötődnek az edzőjükhöz és a sporttevékenységen túli szférában nem alakult ki olyan szoros kapcsolat közöttük. Ez annak is lehet az oka, hogy a határon túli akadémia bentlakásos jellege kevésbé tekint hosszú múltra, így az edzők a sporton kívüli területekre is jobban fókuszálnak még, hogy az ott sportoló, tanuló gyerekek minél könnyebben alkalmazkodjanak ehhez az intézményi formához.

Az edző jellemzői közül az előrelátó, a vezető, irányító és a csapategység kialakítása faktorokat értékelték a legmagasabbra a különbség ellenére 
nemcsak a határon túli játékosok, hanem a hazai labdarúgók is. A két akadémia eltérően ítéli meg az előbb említett edzői tulajdonságokat, azonban a hazai edzők magas értéke az előrelátó tényező esetén azt jelenti, hogy játékosaik úgy tapasztalják, hogy ők is előre megtervezik a feladatokat, célokat tűznek ki. A határon túli labdarúgók ismerik el jobban edzőjük vezetô szerepét és gondolják úgy, hogy a csapategység fejlesztése során, kiemelt hangsúlyt fektetnek a csapaton belüli interakciók minőségére, az együttmúködési készségekre.

Az edzői szerep korosztályi vonatkozása alapján a hazai sportolók közül az U-18-as csapat játékosai tekintik leginkább példaképnek edzőjüket, aki egyben a mindennapi stressz és szorongás csökkentésére is maximális energiát fordít. A csapat tagjai szemében az edző egy tekintély, akire felnéznek, mert nemcsak kizárólag a szakmai munkáért felelős személyt látják benne, hanem elismerik a sporton kívüli területen nyújtott segítségét is. A határon túli csapatoknál érdemes kiemelni, hogy minél idősebbek a játékosok, annál inkább magasabban értékelték edzőjük motivációs tevékenységét és fontos megemlíteni, hogy a legkevésbé motiváló, teljesítményre ösztönző legfiatalabb korosztálynak az edzője is magas pontszámot kapott.

Az edző jellemzőit elemezve, a hazai mintában a korcsoportokat érintő eltérések azt mutatják, hogy minél fiatalabbak a játékosok, annál inkább érzik úgy, hogy az ő edzőjük számára legfontosabb a mérkőzésre való felkészítés az eredményességgel szemben, míg a legidősebb csapat tagjai tartják a leginkább teljesítménycentrikusnak edzőjüket. Minél közelebb kerülnek a fiatal labdarúgók a képzési időszak végéhez, annál inkább az eredménycentrikusság mellett a folyamatos egyéni jó teljesítmény határozza meg a sikerességet. A mérkőzéseken elkövetett hibák akár a későbbi profi szerződés létrejöttét is veszélyeztethetik (Kiss és tsai, 2015). Lindner és Kerr (2001) szerint, a tehetséggondozás sikerességére külső és belső faktorok is hatnak. Jelen kutatásunkhoz hasonlóan ez a kutatás is rávilágít arra, hogy az edző kiemelt figyelmet kap a sportolók részéroól, akik eltérő véleménnyel vannak az edzői szerepekről és tulajdonságokról.

\section{Korlátozások}

A kutatás korlátaihoz tartozik, hogy mindössze egy hazai és egy határon túli akadémia bentlakó labdarúgóit vizsgálta, így az eredmények általánosíthatósága korlátozott. Az egyes korosztályok alacsony elemszáma csökkentette a statisztikai erőt. $\mathrm{Az}$ is befolyásoló tényezőként jelenik meg, hogy az eredmények alapján nem tudunk összehasonlítást végezni a nem bentlakásos rendszerben nevelkedő fiatal labdarúgókkal. Fontos irány lenne ezen összetevők mentén is végezni vizsgálatokat.

\section{Konklúziók}

A kapott eredmények alapján elmondható, hogy a különböző korú fiatal labdarúgó eltérően vélekednek az edzők tevékenységérool és a tulajdonságaikról. Megállapítható, hogy nem csak a szakmai munkáért felelős személyt látják az edzöjükben, hanem igénylik a sporton kívüli tevékenységszférákban is a segítségüket. Példaképként akarnak rájuk tekinteni, akikhez bizalommal fordulhatnak a különböző életkorra jellemző problémáikkal, akik segíthetnek a stresszes élethelyzetek feloldásában és megoldásában. Érdemes edzóknek megszívlelni azt a gondolkodásmódot, hogy nemcsak a sportszakmai feladatokért felelós személyek, hanem az egyéni bánásmódot igénylő gyerekek civil életére is hatással vannak.

A fiatal labdarúgókkal foglalkozó edzőkben megerősödhet az a szemlélet, hogy a pedagógiai tevékenységek kiterjesztése a sporton túli területekre és kommunikáció megfelelő alkalmazása nélkül nem lehetnek sikeresek a labdarúgók tehetségének kibontakoztatásában és a jövő építésében. A közeli jövőben érdemes az edző - sportoló kapcsolatról meglévő információk bővítése, a kutatás további menetében más hazai és határon túli intézményben is végzünk hasonló kutatásokat.

\section{Irodalom}

Bábosik István (1991). A nevelés folyamata és módszerei. Leopárd Könyvkiadó, Budapest.

Baumann, S. (2006). Csapatpszichológia. BudapestPécs, Dialóg Campus Kiadó

Biróné Nagy Edit (szerk.) (2004). Sportpedagógia. Kézrikönyv a testnevelés és sport pedagógiai kérdéseinek. 
tanulmányozásához. Budapest-Pécs, Dialóg Campus Kiadó

Czeizel, E. (1997). Sors és tehetség. Budapest, FITT IMAGE/Minerva Kiadó

Csáki, I., Bognár, J., Trzaskoma-Bicsérdy, G., Zalai, D., Mór, O., Révész, L., \& Géczi G (2013). A sportágválasztás, a tehetséggondozás és az edző-sportoló kapcsolat vizsgálata elit utánpótláskorú labdarúgók körében. Magyar Sporttudományi Szemle, 14.3 (55) 9-16.

Csáki, I., Bognár, J., Révész, L., \& Géczi, G. (2013): Elméletek és gyakorlatok a tehetséges labdarúgó kiválasztásához és beválásához. Magyar Sporttudományi Szemle, 14 : 1 (53) 12-18.

Géczi, G., Révész, L., Bognár, J., Vincze, G., \& Benczenleitner, O. (2005). Talent and talent development in sport: The issue of five sports. $\mathrm{Ka}$ lokagathia, 43(3), 113-123.

Gombocz, J. (2004). A testnevelő tanár és az edző pedagógiai szerepe. In: Biróné Nagy E. (szerk.), Sportpedagógia. Kézikönyv a testnevelés és sport pedagógiai kérdéseinek tanulmányozásához: (147-171) Budapest-Pécs, Dialóg Campus Kiadó.

Gombocz, J. (2010). Sport és nevelés. Keszthely, Balaton Akadémia Kiadó

Gombocz, J., \& Gombocz, G. (2006). Utánpótláskorú sportolók véleménye edzőjükről (Az ideális és reális edző képe 14-16 éves kosárlabdázó fiúk ítéleteiben). Kalokagathia, 1-2, 76-85.

Kiss, Z., Fózer-Selmeci, B., Csáki, I., \& Bognár, J. (2015). Bentlakó labdarúgó-korosztályok pszichés-mentális jellemzői. Mentálhigiéné és Pszichoszomatika. 4, 331-347.

Koltai, M., \& Bognár, J. (2009): Az együttműködés és versengés jellegzetességei a magyar női röplabdázásban sikeres edzők szemszögéből. Kalokagathia, 47-48 : 4-1, 79-98.

Lénárt, Á. (szerk.) (2002). Téthelyzetben. Sportpszichológiáról edzöknek és versenyzöknek. Budapest, Országos Sportegészségügyi Intézet

Lindner, K.J.; Kerr, J. (2001). Predictability of sport participation motivation from metamotivational dominances and orientations. Personality and Induvidual Differences, 30, 759-773.

Makszin, I. (2012). A testnevelés elmélete és módsz̨ertana. Budapest-Pécs, Dialóg Campus Kiadó
Mező, F., Mező, K. (2007). Tanulási stratégiák fejlesztése az IPOO-modell alapján. Debrecen: Tehetségvadász Stúdió - Kocka Kör Tehetséggondozó Kulturális egyesület.

Myers, N.D., Vargas - Tonsing, T.M., \& Feltz, D.L. (2005): Coaching efficacy in intercollegiate coaches: Sources, coaching behavior, and team variables. Psychology of Sport and Exercise, 6: 129143.

Orosz, R. (2010). A sporttehetség felismerésének és fejlesztésének alapjai. Budapest, Magyar Tehetségsegítő Szervezetek Szövetsége

Révész, L., Bognár, J., \& Géczi Gábor (2007). Kiválasztás, tehetség és pedagógiai értékek az úszásban. Új Pedagógiai Szemle, 4. 45-53.

Révész, L., Bognár, J., Csáki, I., \& TrzaskomaBicsérdy, G. (2013). Az edző-sportoló kapcsolat vizsgálata az úszás sportágban. Magyar Pedagógia 113. 1. 53-72.

Révész, L., Géczi, G., Bognár, J., \& Tóth, L. (2005). A sporttehetség megközelítési módjai. Magyar Edzoó: Módszertani és továbbképzó folyóirat 8. 4. 5-7.

Rossmann, E. D. (1987). Verhaltenskonzepte für das sportliche Training von Jugendlichen. Schorndorf, Verlag K. Hoffmann

Szebenyiné és Nyirkos, T. (1986). A személyiségkëapontú világnézeti nevelés módszerei. Budapest, Tankönyvkiadó

Szepes, M. (2002). A mindennapi élet mágiája. Budapest, Édesvíz Kiadó

Trzaskoma-Bicsérdy, G., Bognár, J., Révész, L., \& Géczi, G. (2007). The Coach-Athlete Relationship in Successful Hungarian Individual Sports. International Journal of Sports Science and Coaching 2 .4. 485-495.

Varga, D. (2017). Képben a gyermekkép: Labdarúgó edzők nézetei a mester és utánpótláskorú tanítványai kapcsolatáról. Magyar Sporttudományi Szemle, 71, 46-51.

Vincze, G., Fügedi, B., Dancs, H., \& Bognár, J. (2008). The effect of the 1989-1990 political transition in Hungary on the development and training of football talent. Kinesiology 40: 1. 5060. 